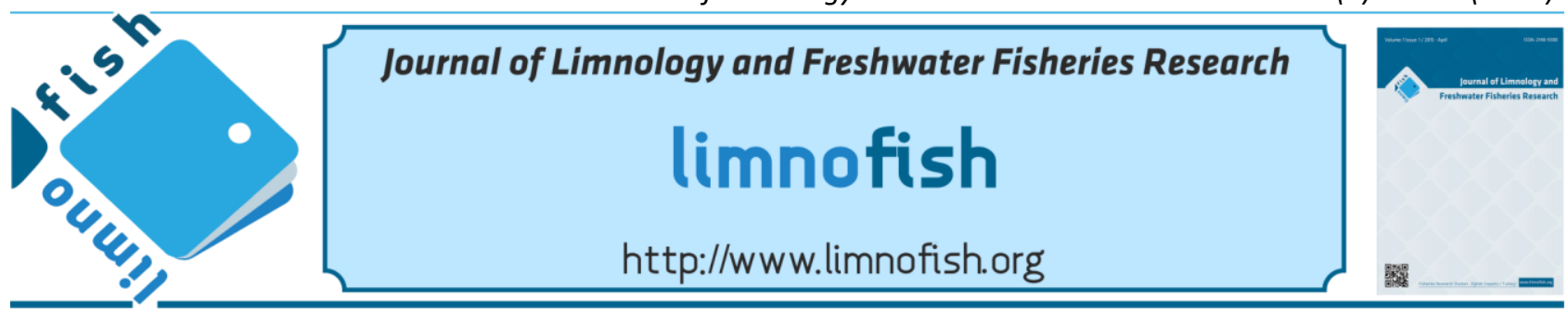

Behavioral Differentiation Induced by Insecticide Lambda-Cyhalothrin in Mosquito Fish, Gambusia affinis

\title{
Utku GÜNER
}

Trakya University, Faculty of Sciences, Department of Biology, 22030 Edirne, Türkiye

\section{A B STRACT}

Test toxic material, one of most used pesticide, the Lambda cyhalothrin ( $L C Y)$ (TEKVANDO 5EC) belongs to a group of chemicals called synthetic pyrethroids and pesticides and potential toxic pollutant contaminating aquatic ecosystems, was investigated in the present study for behavioral toxicology. Mosquito fish, Gambusia affinis (Baird \& Girard, 1853) were selected for responses of Lambda cyhalothrin by Using to video-based movement analysis system. Selected 3 different doses $0.1,0.5$ and $0.75 \mathrm{ppm}$ were used analyzed behavioral changes according to control group. The following behaviors were measured: total distance, travelled and average speed for treatment and control groups, maximum and average speed and time moving away from the dose applied point. This suggests that $L C Y$ contamination has the potential to significantly affect $(p<0.05)$ the behavior of Mosquito fish, G. affinis.

Keywords: Gambusia affinis, behavioral toxicology, lambda cyhalothrin, toxic effect

\section{ARTICLE INFO}

RESEARCH ARTICLE

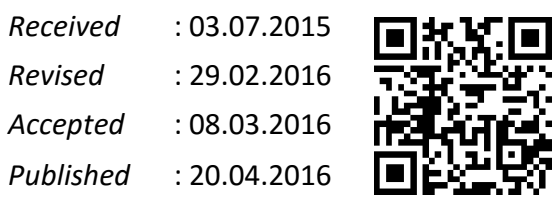

DOI: 10.17216/LimnoFish-5000128861

* CORRESPONDING AUTHOR

uguner@trakya.edu.tr

Tel : +905426218622

Fax: +902842354010

\section{Insektisit Lambda Cyhalothrin Maruz Bırakılan Sivrisinek Balığı Gambusia affinis’te Davranış Değişimi}

Öz: İnsektisitler, sucul ekosistemde insan kaynaklı toksik kirleticilerin başında gelmektedir. Bu çalışmada, bir isektisit olan lambdacyhalothrin $(L C Y)$ 'in farklı dozlarının sivrisinek balığında toksik etkiye bağlı davranışsal etkileri aştırılmıştır. Sentetik piretroidler ve böcek ilaçları ve potansiyel toksik kirletici olarak sucul ekosistemlerin kirlenmesine neden başlıca kirleticiler arasındadır. Sivrisinek balığı, Gambusia affinis (Baird \& Girard, 1853) video tabanlı hareket analizi sistemi kullanarak söz konusu pestisite verilen cevaplar ortaya çıkarılması için kullanmıştır. Seçilen 3 farklı doz $0,1,0,5$ ve 0,75 ppm ve kontrol grubuna göre yapılana analizler davranış değişikliklerin belirlenmesinde kullanılmıştır. Çalışmada araştırılan davranış parametreleri; toplam mesafe, hareket mesafesi ve ortalama hız, uygulanan noktaya göre hareket miktarı hem uygulama hem de kontrol grupları için, maksimum ve ortalama hız ve süredir. Bu çalışma, $L C Y$ 'nin sivrisinek balığı, G. affinis davranışlarını önemli ölçüde etkileme potansiyeline $(p<0,05)$ sahip olduğunu göstermektedir.

Anahtar kelimeler: Gambusia affinis, davranışsal toksikoloji, lambda cyhalothrin, toksik etki

How to Cite

Güner U. 2016. Behavioral Differentiation Induced by Insecticide Lambda-Cyhalothrin in Mosquito Fish, Gambusia affinis. LimnoFish. 2(1):11-17. doi: 10.17216/LimnoFish-5000128861

\section{Introduction}

Today, pesticides are playing a very important role in modern agriculture. Because they reduce the total crop losses of pesticides is relatively reliable, durable and relatively complete control. Also pests with minimal costs and effort they have, increase crop yields by killing. However Pesticide are one of the strongest polluting the water environment (Murty 1986). Pesticide are considered as potent pollutants of the water environment with undesirable effects on non-target organisms such as fish and water animals (Guner 2009; Hoagland et al. 1993; Khan et al. 2012).

Fish are ideal sentinels and test organisms for behavioral assays of various stress factors and toxic chemicals (such as heavy metals and pesticide) exposure due to their ecological relevance in many natural systems (Frrat et al. 2011; Xin et al. 2015).

Many environmental stress affected fish behavior (Osten et al. 2005). Environmental stress may change depending on fish behavior. Therefore, a change in behavior and toxicological effects of environmental 
risk assessment analysis is a useful tool for environmental risk assessment and analysis of toxicological impact (Rao et al. 2006). There are numerous technical and biological factors have made sublethal effects on fish behavior (Kane et al. 2004). It is used more often with extreme behavior. Neurotoxicology effect on the nervous system is used to identify the negative effects of chemical substances and characterized (Evangelista de Duffard and Duffard 1996).

Like other pyrethroids, LCY disrupts the nervous system in insects, causing paralysis and death. Pyrethroids insecticides bind to voltage-sensitive sodium channels and modify their gating kinetics, thereby disrupting nerve functions and producing acute neurotoxic effects in both insects and nontarget organisms (Choi and Soderlund 2006).

Sublethal exposure to chemicals often causes changes in swimming behavior, reflecting alterations in sensory and motor systems. Swimming behavior also integrates functions of the nervous system (Brewer et al. 1999). Changing behavior of fish is varied. This kind of change in behavioral patterns, such as color changes, skin, hyperactivity, loss of balance, speed swimming, increased surface activity, opercula activities improved rate, significantly in fish (Clarias batrachus) were observed (Kumar et al. 2011).

The present test animal, Gambusia affinis (Baird and Girard, 1853) is a member of Poeciliinae subfamily of Poeciliidae (Poeciliids) and inhabits standing to slow-flowing water but are most common in vegetated ponds and lakes and quiet pools of streams (Muranli and Guner 2011). G. affinis feeds on zooplankton, small insects and detritus and are used as live food for carnivorous aquarium fishes. $L C Y$ runoff from agricultural fields killed natural fish populations in great amount ( $\mathrm{Gu}$ et al. 2007) in masses in various parts of the world also, in addition, recent research has shown that exposure to lambda cyhalothrin, even at sublethal doses, induces behavioral and biochemical changes in fish (Guet al. 2007; Guner 2012; Muranli and Guner 2011).

Since $G$. affinis was a widespread organism and was used for biological control of mosquito (Muranli and Guner 2011) and to demonstrate effects on non-target organisms' behavior changes, this study was undertaken to evaluate behavioral effects of lambda cyhalothrin on $G$. affinis in controlled laboratory environment.

\section{Materials and Methods}

Lambda-cyhalothrin (mixture $1: 1$ of $\mathrm{S}$ and $\mathrm{R}$ isomers); molecular Formula $\mathrm{C}_{23} \mathrm{H}_{19} \mathrm{ClF}_{3} \mathrm{NO}_{3}$ (CAS no: 91465-08-6), emulsion concentration is $50 \mathrm{mg} / \mathrm{l}$. Commercial grade lambda cyhalothrin (Tekvando 5EC) (proved by Sefa Tarım A.Ş, Turkey) was used in this study. The 96-h $\mathrm{LC}_{50}$ value for mosquito fish was estimated as $1.107 \mu \mathrm{g} / 1$ (Guner 2009).

\section{Fish employed}

Mosquito fish ( $G$. affinis) were obtained from Güllapoğlu Lake, Edirne Turkey in October 2012 and held in flowing dechlorinated (active carbon filtered) Edirne city tap water. They were transferred to glass aquarium $(50 \times 50 \times 100 \mathrm{~cm}, 100 \mathrm{~L})$ in the aquarium room and maintained at $20{ }^{\circ} \mathrm{C}, 14: 10$ light: dark regime. This arrangement was left undisturbed for seven days, during which animals became accustomed to room conditions. Dechlorinated aquarium water was aerated by air pump for over $24 \mathrm{~h}$. Male and female adult fish were maintained in dechlorinated tap water at $20{ }^{\circ} \mathrm{C}$ under a 14L:10D photoperiod, with a diet of commercial fish flakes (Tetra Min Pul). Treatment (3 fish per doses) and control groups consist of 3 fishes. The fish used were adult both females and males between 20 and $30 \mathrm{~mm}$ total length (about $<1 \mathrm{~g}$ ). They were transferred to 1 liter polypropylene (r: $170 \mathrm{~mm}$, depth: $80 \mathrm{~mm}$ ) container for tests. Water parameters during the experiment remained constant as follows: dissolved oxygen $11.83 \pm 2.511 \mathrm{mg} / \mathrm{l}$, temperature $20 \pm 2{ }^{\circ} \mathrm{C}, \mathrm{pH}$ $8.19 \pm 0.92$, and conductivity $632.198 \pm 9.98 \mu$ hos.

\section{Experimental system hardware and software}

The video output from the camera was fed to a computer running an animal movement tracking software (Any-Maze Version 4.69). After $5 \mathrm{~min}$ of acclimation, the movement of each fish in aqua was recorded with the video USB camera (SN9C105 model $640 \times 480$ pixels) for 5 minutes.

\section{Apparatus}

$L C Y$ applied (doses $0.1,0.5$ and $0.75 \mathrm{ppm}$ ) on center point of apparatus (Figure 1) by ependoft multi pipette. And also figure 2 shows dose applied in the apparatus. 3 fish was tested all doses groups $(0.1,0.5$ and $0.75 \mathrm{ppm}$ ) and control group. When calculating the distance of the animal from this point, the system will use the distance from the part of the animal closest to the point.

\section{Zones}

Figure 2 shows the area(s) in the apparatus which correspond to the zones determined. Four different zones were defined. The system considered an animal to be in a particular zone whenever its center point is within this zone (Figure 2). 

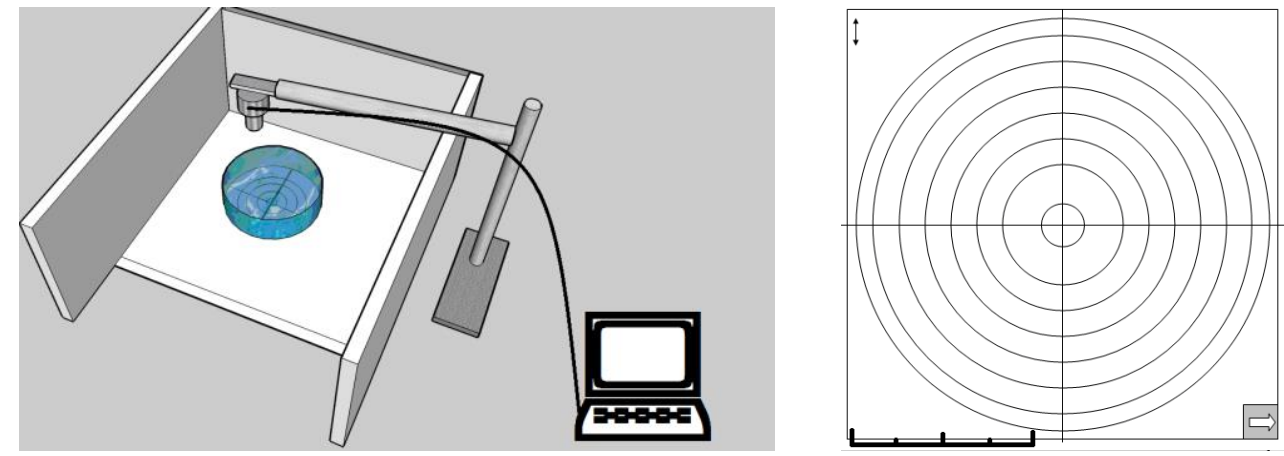

Figure 1. Toxic test system and apparatus map (Guner 2013).

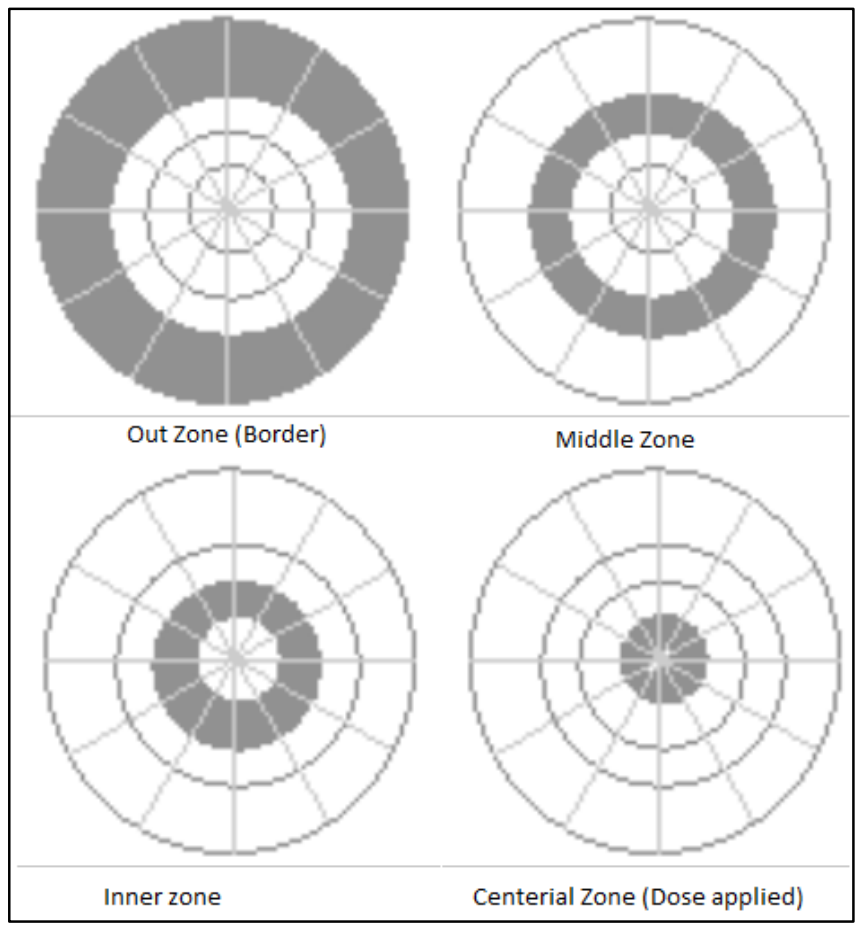

Figure 2. Positions of the zones in the toxic test apparatus.

\section{Results}

After 5 min of acclimation, the movement of each fish in aqua was recorded and analyzed. Some fish behavior mean and standard deviation of the parameters analyzed are listed below the table (Table 1) and graphs to control exposures and doses (Figure 3, Figure 4, Figure 5 and Figure 6). Traces path taken during the experiments during the experimental period of the fish were shown Figure 3.

Table 1. Some fish behavior parameters mean and standard deviation.

\begin{tabular}{|c|c|c|c|}
\hline Treatment & Control & $L C Y 0.5 \mathrm{ppm}$ & $L C Y 0.75 \mathrm{ppm}$ \\
\hline $\mathrm{N}$ & 10 & 5 & 5 \\
\hline Average speed $(\mathrm{m} / \mathrm{s})$ & $0.023 \pm 0.0051$ & $0.0230 \pm 0.0115$ & $0.0274 \pm 0.0062$ \\
\hline Maximum speed (m/s) & $0.637 \pm 0.1903$ & $0.623 \pm 0.0883$ & $0.680 \pm 0.1234$ \\
\hline $\begin{array}{l}\text { Total distance travelled by the animal's head } \\
\text { (m) }\end{array}$ & $6.549 \pm 1.2488$ & $6.399 \pm 4.3405$ & $6.773 \pm 2.3667$ \\
\hline Average distance from the dose point (m) & $0.098 \pm 0.0070$ & $0.103 \pm 0.0084$ & $0.098 \pm 0.0023$ \\
\hline Time moving away from the dose point (s) & $22.08 \pm 6.45$ & $20.16 \pm 13.80$ & $26.54 \pm 4.23$ \\
\hline
\end{tabular}




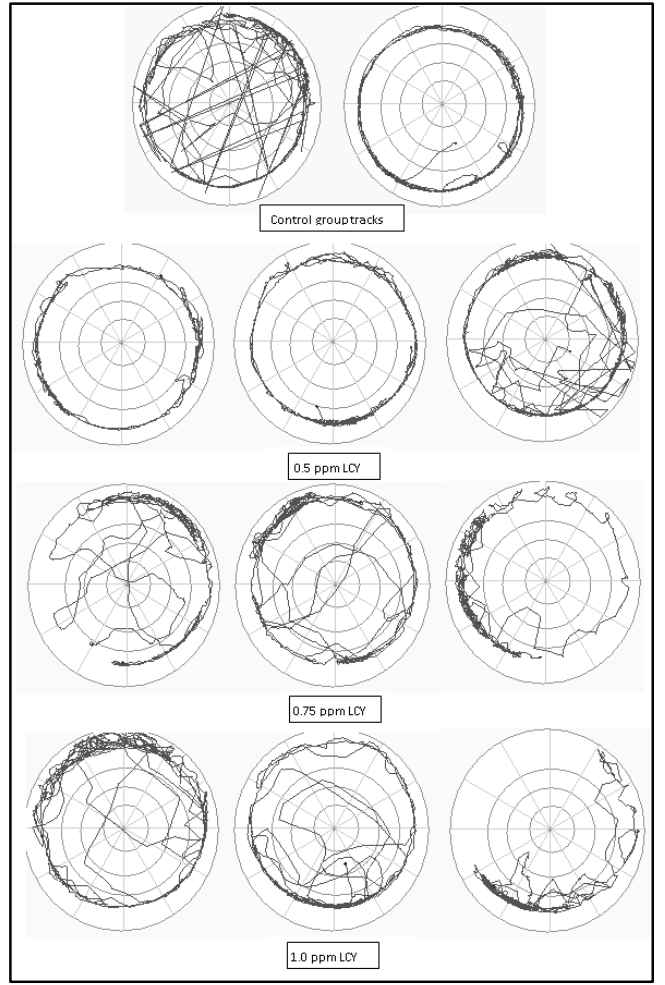

Figure 3. The track plots of the animals during tests.

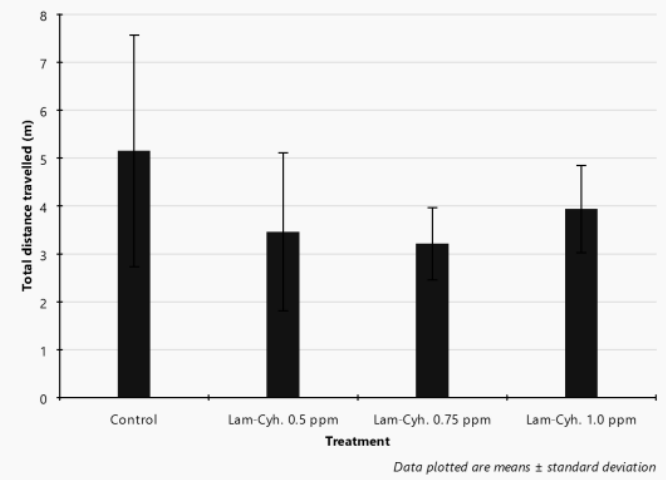

(a)

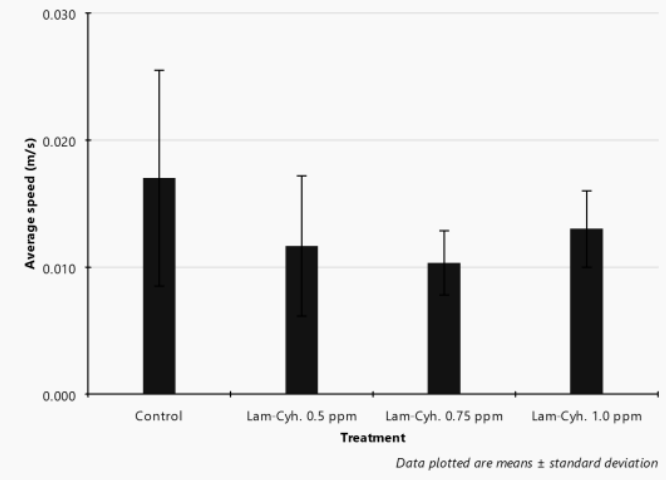

(b)

Figure 4. a) Total distance travelled and b) average speed for treatment and control group.

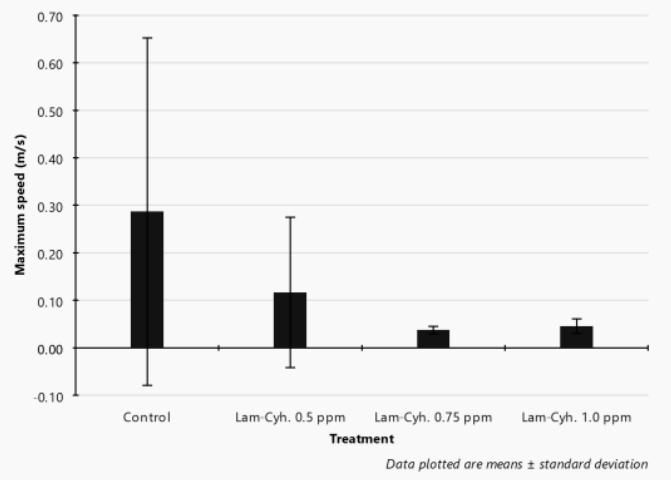

(a)

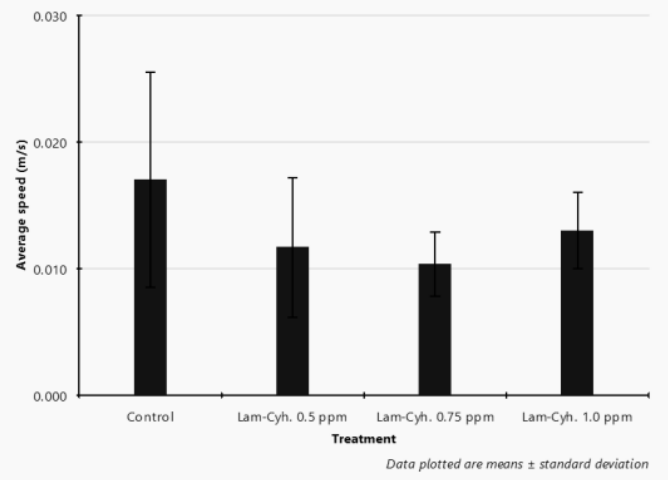

(b)

Figure 5. a) Maximum and b) average speeds for test groups. 
The results obtained from the experiments are summarized below:

- Swimming behavior of the fish was affected with different doses of Lambda-cyhalothrin $(0.1,0.5$ and $0.75 \mathrm{ppm}$ ).

- The comparison of treatment and dose groups showed that swimming speeds in dose groups were slower $(p<0.05)$.

- Depending on the amount of pesticide avoidance behavior of fish was determined that the point of application.

- When the test pesticide was applied in the test box, the fish has chosen the external regions of the boxes possibly for protection (see on figure 3 ).

\section{Discussion}

During the experiments, no mortality was observed in both of control and exposure groups. Although, under laboratory conditions of constant toxicant concentrations, lambda-cyhalothrin was highly toxic for fish (96-hour LC50 value of $L C Y$ was $1.107 \mu \mathrm{g} / \mathrm{l})$ and aquatic invertebrates (Caliani et al. 2009; Guner 2009).

Fish are ideal experimental objects for behavioral assays of various stressors and toxic chemical exposure due to their: (I) constant, direct contact with the aquatic environment where chemical exposure occurs over the entire body surface; (II) ecological relevance in many natural systems (III) ease of culture; (IV) ability to come into reproductive readiness and $(\mathrm{V})$ long history of use in behavioral toxicology. Alterations in fish behavior, particularly in non-migratory species, are also important indices for ecosystem assessment (Kaneet al. 2004). This study examined different parameters in fish behavior. In a short time (5 minutes) were observed behavioral changes due to the effect of LYC exposure. Fish behavior changes were observed in a similar study. The fish in toxic media (insecticide, malathion $50 \%$ EC) exhibited irregular, random, circular swimming movements, hyperexcitability, loss of equilibrium, and sinking to the bottom (Patil and David 2010).

It was reported that lambda-cyhalothrin were determined at different tissues and organs of fish such as blood, liver, brain, spinal cord, sciatic nerve, vas deferens, anococcygeus and myenteric plexus tissue. And also, plasma, liver, hypothalamus, cerebellum, medulla oblongata, frontal cortex, striatum, hippocampus, midbrain, spinal cord, vas deferens, anococcygeus, myenteric plexus and sciatic nerve concentrations of lambda-cyhalothrin were determined by HPLC (Anadon et al. 2006). Lambda-cyhalothrin in different fish tissues may have lead to behavior change.
$L C Y$ directly affects the nervous system. The histological studies indicate that LCT doses induced both axon or myelin degeneration, myelin sheath separation and vacuolization in nerve fibers. The results suggest that LCT had a neurotoxic potential (Askin et al. 2010).

Image analysis can be a useful tool for evaluating the effectiveness of flatfish behavior and welfare work. Accordingly, with the night life of the motor activity of the species in mind that a single population, were recorded by digital video for three nights. Subsequent image analysis was performed by sequential extraction of a frame image. Result show that $\mathrm{s}$ digital video-based index can be a highly reliable and accurate method for objectively measuring activity levels in sole with a low consumption of labor and time (Duarte et al. 2009). In this study, video-based digital image analysis hardware and software has been used. The system compares the results with different exposure dose and control group (see Figure 2, Figure 3, Figure 4, Figure 5 and Table 1).

Sublethal exposure to chemicals often causes changes in swimming behavior, reflecting alterations in sensory and motor systems. Swimming behavior also integrates functions of the nervous system. Rarely are the connections between physiology and behavior made. Although behavior is often suggested as a sensitive, early indicator of toxicity, behavioral toxicology has not been used to its full potential because conventional methods of behavioral assessment have relied on manual techniques, which are often time-consuming and difficult to quantify. This has severely limited the application and utility of behavioral procedures. Swimming behavior is particularly amenable to computerized assessment and automated monitoring. Locomotory responses are sensitive to toxicants and can be easily measured (Breweret al. 1999). Locomotory responses in this study, particularly Average speed and Maximum speed parameter shows the difference between the control and exposure groups.

This behavioral exposure, tracking, and analysis system can be applied to quantify differences in behavior associated with exposure to organic pollutants, heavy metals, pesticides, harmful algal bloom toxins and physical effects such as thermal pollution, radiation, vibration (sound). This behavioral exposure, tracking, and analysis automation system is made easily available for different organisms. In addition, the system has some advantages as a low cost, great benefits, speed, and accuracy with a large data set. Behavioral alterations, as identified by this movement tracking hardware and software system, also provides a potential tool for the quantification of differences in reproductive 
behaviors, predator-prey interactions, behavioral changes across environmental gradients, and differences in swimming behavior between species. Analysis of behavioral responses to a variety of stimuli can provide quantitative measures of neural and mechanical disruption, reflecting biochemical and physiological alterations (Xie et al. 2015).

In this study, three different doses chosen for $L C Y$ $0.1,0.5$ and $0.75 \mathrm{ppm}$ were applied to the fish. Exposure depends on the behavior of analyzes conducted and control groups were used to determine the changes. This study depend $L C Y$ pollution mosquito fish; G. affinis shows that it has the potential to significantly influence behavior.

\section{References}

Anadon A, Martinez M, Martinez MA, Diaz MJ, Martinez-Larranaga MR. 2006. Toxicokinetics of lambda-cyhalothrin in rats. Toxicol Lett. 165(1):47-56. doi: 10.1016/j.toxlet.2006.01.014

Askin A, Comelekoglu U, Yilmaz BC, Yalin S, Aktas S, Mazmanci B, Camlica Y, Celik A. 2010. Neurotoxic actions of lambda-cyhalothrin on rat sciatic nerve. Fresen Environ Bull. 19(1):100-107

Brewer SK, DeLonay AJ, Beauvais SL, Little EE, Jones SB. 1999. The use of automated monitoring to assess behavioral toxicology in fish: Linking behavior and physiology. Am Soc Test Mater. 1364:370-386. doi: $10.1520 / \operatorname{Stp} 15816 \mathrm{~s}$

Caliani I, Porcelloni S, Mori G, Frenzilli G, Ferraro M, Marsili L, Casini S, Fossi MC. 2009. Genotoxic effects of produced waters in mosquito fish (Gambusia affinis). Ecotoxicology. 18(1):75-80. doi: 10.1007/s10646-008-0259-0

Choi J-S, Soderlund DM. 2006. Structure-activity relationships for the action of 11 pyrethroid insecticides on rat Nav1.8 sodium channels expressed in Xenopus oocytes. Toxicol Appl Pharm. 211(3):233-244. doi: 10.1016/j.taap.2005.06.022

Duarte S, Reig L, Oca J. 2009. Measurement of sole activity by digital image analysis. Aquacult Eng. 41(1):22-27. doi: 10.1016/j.aquaeng.2009.06.001

Evangelista de Duffard AM, Duffard R. 1996. Behavioral toxicology, risk assessment, and chlorinated hydrocarbons. Environ Health Persp. 104(Suppl 2):353-60. doi: 10.1289/ehp.96104s2353

Firat Ö, Cogun HY, Yüzereroğlu TA, Gök G, Firat Ö, Kargin F, Kötemen Y. 2011. A comparative study on the effects of a pesticide (Cypermethrin) and two metals (copper, lead) to serum biochemistry of Nile tilapia, Oreochromis niloticus. Fish Physiol Biochem.
37(3):657-666

doi: 10.1007/s10695-011-9466-3

Gu BG, Wang HM, Chen WL, Cai DJ, Shan ZJ. 2007. Risk assessment of lambda-cyhalothrin on aquatic organisms in paddy field in China. Regul Toxicol Pharm. 48(1):69-74. doi: 10.1016/j.yrtph.2007.01.005

Guner U. 2012. Alüminyumun, Farklı pH Değerlerinde Gambusia affinis (Baird \& Girard, 1853) Üzerine Toksisitesi. Paper presented at: V. National Symposium on Limnology; Isparta, Turkey

Guner U. 2009. Determination of lambda cyhalotrin (Tekvando 5EC) 96 hour lethaldose 50 at Gambusia affinis (Baird \& Girard, 1853). J FisheriesSciences.com. 3(3):214-219.

Guner U. 2013. Behavioral Changes Induced by Neonicotinoid insecticide Acetamiprid in freshwater shrimp (Caridina nilotica). Anadolu Doğa Bil Derg. 4(1):6-10.

Hoagland KD, Drenner RW, Smith JD, Cross DR. 1993. Freshwater community responses to mixtures of agricultural pesticides: Effects of atrazine and bifenthrin. Environ Toxicol Chem. 12(4):627-637.

doi: $10.1002 /$ etc. 5620120404

Kane AS, Salierno JD, Gipson GT, Molteno TCA, Hunter C. 2004. A video-based movement analysis system to quantify behavioral stress responses of fish. Water Res. 38(18):3993-4001.

doi: 10.1016/j.watres.2004.06.028

Khan A, Ahmad L, Khan MZ. 2012. Hemato-biochemical changes induced by pyrethroid insecticides in avian, fish and mammalian species. Int J Agr Biol. 4(5):834-842.

Kumar A, Sharma B, Pandey RS. 2011. Assessment of acute toxicity of lambda-cyhalothrin to a freshwater catfish, Clarias batrachus. Environ Chem Lett. 9(1):43-46.

doi: $10.1007 / \mathrm{s} 10311-009-0244-8$

Muranli FDG, Guner U. 2011. Induction of micronuclei and nuclear abnormalities in erythrocytes of mosquito fish (Gambusia affinis) following exposure to the pyrethroid insecticide lambda-cyhalothrin. Mutat Res-Gen Tox En. 726(2):104-108.

Murty AS. 1986. Toxicity of Pesticides to Fish. Volume 2. United States: CRC Press Inc.,Boca Raton, FL.

Osten R-v, Ortiz-Arana A, Guilhermino L, Soares AMVM. 2005. In vivo evaluation of three biomarkers in the mosquitofish (Gambusia yucatana) exposed to pesticides. Chemosphere. 58(5):627-636. doi 10.1016/j.chemosphere.2004.08.065

Patil VK, David M. 2010. Behavioral and morphological endpoints: as an early response to sublethal malathion intoxication in the freshwater fish, Labeo rohita. Drug Chem Toxicol. 33(2):160-165. doi: $10.3109 / 01480540903196816$ 
Rao JV, Begum G, Jakka NM, Srikanth K, Rao RN. 2006. Sublethal effects of profenofos on locomotor behavior and gill architecture of the mosquito fish, Gambusia affinis. Drug Chem Toxic. 29(3):255-267. doi: 10.1080/01480540600651543

Xie ZX, Lu GH, Li S, Nie Y, Ma BN, Liu JC. 2015. Behavioral and biochemical responses in freshwater fish Carassius auratus exposed to sertraline. Chemosphere. 135:146-155. doi: 10.1016/j.chemosphere.2015.04.031

Xin Z, Wenchao Z, Zhenguang $\mathrm{Y}$, Yiguo $\mathrm{H}$, Zhengtao L, Xianliang Y, Xiaonan W, Tingting L, Liming Z. 2015. Species sensitivity analysis of heavy metals to freshwater organisms. Ecotoxicology.

doi: 10.1007/s10646-015-1500-2 